\title{
SEDENTARY LIFESTYLE MAY CONTRIBUTE TO THE RISK OF DEPRESSION DURING THE COVID-19 PANDEMIC
}

\section{A Snapshot of Hungarian Adolescents}

(Received: 09 February 2021; accepted: 28 September 2021)

Background: Social exclusion usually contributes to an increased vulnerability to mental health problems and risky health behaviors. This study aims to identify the role of health behavior in the increased risk of depressive symptoms among adolescents during the coronavirus pandemic in Hungary.

Methods: A total of 705 high school students participated in our study $(\mathrm{M}=15.9$ years; $\mathrm{SD}=$ 1.19). The self-administered questionnaire included items about sociodemographics, eating habits, physical activity, sedentary behavior, and substance use. Depressive symptoms were measured using the short version of the Child Depression Inventory. Descriptive statistics and binary logistic regression were used to analyze our results.

Results: Daily fruit and vegetable consumption was reported by $21.7 \%$ and $22.4 \%$ of respondents, respectively. The proportion of the respondents reporting daily sweets consumption stood at $13.2 \%$, daily soft drinks consumption was $12.3 \%$, and daily energy drink consumption tallied to $4.5 \%$. More than one-third of the sample $(35.5 \%)$ reported having breakfast every school day, which rose to $68.1 \%$ of the sample reporting breakfast on both weekend days. The rate of students engaged in daily physical activity was $6.5 \%$, while $86.1 \%$ of them reported more than four hours screen time in a day. In addition, despite the mandatory confinement, a notable percentage of adolescents engaged in substance use. Consistent with previous studies, girls had a higher risk of depression. Low levels of physical activity and high levels of screen time - as well as alcohol and drug use - were associated with a high risk of depression.

Conclusions: We believe our study provided useful information on adolescent health behaviors that can lead to adolescents' depression, and that maintaining physical activity can prevent it even in these unusual circumstances.

Keywords: health behavior; physical activity; eating behavior; substance use; mental health

* Corresponding author: Dr. Tamas Berki, Institution of Education and Sport Sciences, Faculty of Education, University of Szeged, Hattyas u. 10. Szeged 6725, Hungary; berki.tamas.laszlo@szte.hu. 


\section{Introduction}

The coronavirus (COVID-19) epidemic has affected daily life worldwide; Hungary, like many other countries, applied several restrictions to slow the spread of the virus through increased social distancing. The restrictions impacted offices, restaurants, cinemas, sports facilities, and schools since the governments closed down such services. While these regulations might have helped slow the epidemic, social isolation during the quarantine increased vulnerability to mental health problems and risky health behaviors (e.g., BATES et al. 2020). Several studies reported psychological and behavioral effects, such as increased stress, anxiety, or insomnia (e.g., PAPPA et al. 2020). Furthermore, a high risk of depression was also found in many cases (e.g., CHen et al. 2020). In addition, these variables are strongly associated and co-occur: there is a close correlation between depression and other behavioral problems due to elevated stress levels (CARroll et al. 2020).

Many factors can be associated with depression, including sociodemographics: socioeconomic status, gender, educational level, and income (e.g., ASSARI 2017). A close connection exists between depression and health behavior, such as eating habits (LEE \& ALLEN 2021), substance use (HODDER et al. 2016), physical activity, and sedentary behavior (FENG et al. 2014). These associations were also found in coronavirus related studies. DUAN and colleagues (2020) found that gender, age, place of residence, education level, and family status were correlated with depression and anxiety in an adolescent sample during the COVID-19 pandemic.

The association between eating behavior and depression has been well documented (LEE \& ALLEN 2021). Several studies found negative changes in meal routines during the lockdown period. For example, CARROLL and colleagues (2020) reported increased snack consumption and more cooking time. Another study done by AMMAR and colleagues (2020) found similar changes. They reported unhealthier meal patterns (AMmar et al. 2020). According to SidOR and RZYMSKI (2020), half of the examined adults reported eating more than usual during the quarantine regime. The 'stay-at-home' period also has a role in adolescents' lifestyle and their eating habits. School closure was found as a mediator for the lack of appetite (JIAO et al. 2020), with a significant reduction in daily fruit and vegetable consumption being reported as well (LóPEZ-BuENo et al. 2020). We might hypothesize that changes in their eating behavior could affect their mental well-being and depression during this period; however, there is a lack of studies about the role of eating habits in depression among adolescents.

Another important factor that may contribute to a lower level of mental well-being is physical activity (PIEH et al. 2020), since the lack of it may increase the risk factor development (e.g., Aoun et al. 2019; Hodder et al. 2016). Parallel with the reduction of social interactions and the lockdown of sports facilities, there was a decrease in levels of physical activity and an increase in sedentary behavior (BATES 
et al. 2020). It is well established that physical activity has a protective role against depression (FENG et al. 2014). Not surprisingly, most studies report that significant decreases in physical exercise and increased screen time were associated with a higher tendency to depressive symptoms (ZHOU et al. 2020). A similar trend was reported in Hungary as well. Ács and colleagues (2020) surveyed university students to rate their level of physical activity and sedentary behavior before and after the quarantine mandate was ordered. They found that physical activity was significantly lower and sedentary behavior was significantly higher during home confinement. Another study by MORVAY-SEY and colleagues (2020) found that vigorous physical activity decreased by 40 minutes per week in the first wave of the pandemic. Kovács and colleagues found similar results involving adolescents (2021). According to their study, only one out of five children met the WHO (World Health Organisation 2013) guidelines.

Empirical evidence exists that a lack of social interactions could lead to elevated levels of substance use, with both being associated with mental health problems such as depression (FAIRBAIRN \& SAYETTE 2014). Lack of social networks, mental health problems, and substance use can form a vicious cycle. Isolated individuals are more likely to abuse drugs (HAWKLEY \& CACIOPPO 2010), smoke cigarettes (DYAL \& Valente 2015), and use alcohol (CAnham et al. 2016). Studies associated with the pandemic support these findings. For example, CZEISLER and colleagues (2020) found increased substance use to be a coping mechanism for the stress or emotions related to the economic impacts of the COVID-19 epidemic (e.g., unpaid holiday, job loss). However, a lack of empirical investigation exists for substance use among adolescents during the pandemic. Recent research on this topic showed that while the percentage of adolescents who used substances decreased, the frequency of use increased among Canadian adolescents (Dumas et al. 2020).

These research findings suggest that it would be important to investigate correlates of depression, such as eating behaviors, physical activity, or substance use, during the 'stay-at-home' period. We assume that there is a close connection between depression and health behaviors. Learning more about the role of health behaviors in depressive symptoms may be particularly important since a high level of depression is associated with coronavirus symptoms (RAN et al. 2020), and certain forms of unhealthy behaviors can affect the progression of COVID-19 as well (e.g., smoking is a risk factor for the progression of COVID-19; PATANAVANICH \& GLANTZ 2020).

Furthermore, the long-term effects of the pandemic on health behavior are still unknown. The Hungarian government ordered remote learning for high schools in the first wave (from March 17 to June 15, 2020) and the second wave (from November 11 to May 10, 2021) of the pandemic (MonOsTORI 2021). Thus, the students were away from school approximately half of the academic year. We assume these unusual circumstances could affect both their health behavior and mental health.

Based on the literature and findings from previous studies, the primary goals of this study were twofold. First, this study aimed to explore the prevalence of health 
behaviors such as healthy eating habits, physical activity, sedentary behavior, and substance use during the 'stay-at-home' era. Second, since developing depressive symptoms often increases in such challenging situations (BHATIA \& BHATIA 2007), we aimed to identify the role that sociodemographics and health behaviors (eating behavior and physical activity and substance use) might play in elevating the risk of depressive symptomatology in a sample of Hungarian adolescents after governmental restrictions were applied.

\section{Material and methods}

\subsection{Sample and procedure}

Ethical approval for this study was sought and obtained from the university's Institutional Review Board. The survey was launched three weeks after the Hungarian government ordered school closure for the high schools. Thus, the data collection occurred from December 6 to December 20, 2020. The online survey was voluntary, and recruitment occurred via social media (e.g., Facebook). It took approximately ten minutes to complete. In the survey instructions, the participants were asked to think about their activities, eating behavior, and substance use in the 'stay-at-home' period. The participants were ensured that the data was collected anonymously without IP addresses, GPS tracking, and no identifying data such as names were collected. All the participants provided informed consent online to participate in the study. A total of 719 high school students completed our online survey. However, 14 students were removed due to a failure to complete the survey correctly. Thus, our final sample involved 705 adolescents ranging from 14 to 19 years old. It included 264 boys $(\mathrm{M}=15.8$ years; $\mathrm{SD}=1.09)$ and 441 girls $(\mathrm{M}=$ 16.0 years; $\mathrm{SD}=1.27$ ).

\subsection{Measures}

The survey in the present study was based on the questionnaire of the International Health Behavior in School-aged Children (HBSC) survey. HBSC is a cross-national study of adolescent health and well-being that examines several health behaviors factors such as eating behavior, oral health, injuries, physical activity, sedentary behavior, body image, and bullying (INCHLEY et al. 2020). Our study included only the following topics: eating behavior, physical activity, sedentary behavior and substance use. Besides these, the self-administered questionnaire included socio-demographic data (e.g., age, gender, education, and family background) and questions about depressive symptomatology. 


\subsubsection{Eating habits}

Eating habits were measured with specific questions from the Hungarian version of the HBSC questionnaire (NÉMETH 2014), such as 'How many times a week do you consume: fruit/vegetables/sweets/soft drinks (e.g., cola)/energy drinks?' The response categories were: never, less than once a week, two to four times a week, five to six times a week, once a day, and more than once a day. These variables were dichotomized as 'once a day or more' and 'less than once a day' and daily food/drink consumption was determined.

Besides eating habits, the frequency of having breakfast was asked with the question 'How do you usually have breakfast on school days/on the weekends?' (Response categories for weekdays were: never/one day/two days/three days/four days/five days; for the weekends: never/only on one day/on both days). Responses that indicated daily breakfast consumption (five days/on both days) were used to create dichotomized variables similar to the food/drink consumption measures.

\subsubsection{Physical activity and sedentary behavior}

Physical activity and screen time were determined from specific items from the HBSC study. The following questions measured physical activity: 'Over the past 7 days, on how many days were you physically active for a total of at least $60 \mathrm{~min}$ per day? Please add up all the time you spent in physical activity each day.' (BоBAKovA et al. 2015, 61). The response categories ranged from 0 to 7; however, it was recoded for analysis as follows: 7 days a week; 5-6 days; 3-4 days; $1-2$ days; none.

Sedentary behavior was measured by screen time activities. The students were asked to estimate their screen time in the last seven days (e.g., 'How many hours a day do you spend using electronic devices such as a computer, tablet or smartphone'). Response categories were from 0 to more than seven hours (NÉMETH 2014), and were categorized as the following: less than 1 hour; $2-3$ hours; 4 or more hours.

\subsubsection{Substance use}

Smoking, alcohol use, and drug abuse were measured with separate single questions, a standard method among researchers to assess substance use (e.g., BEHROUZ \& AACHI 2017; HARAKEH et al. 2012). The students were asked to think about their time during the 'stay-at-home' period and indicate their frequency of these types of substance use. Answer categories were coded as 'daily'; 'less than once a week'; 'at least once a week'; 'never'. The variables were dichotomized as never used and occasional/daily use in the 'stay-at-home' period. 


\subsubsection{Child Depression Inventory}

Depressive symptoms were measured with a short version of the Child Depression Inventory (CDI) based on the Health Behavior of School-Aged Children (HBSC) studies (KöLTő 2014). This version provided a possibility of comparing data with a national representative sample. The scale contained eight items. Each was scored on a three-point scale and then coded from 0 to $2(0=$ not at all; $1=$ moderate; $2=$ severe) for each symptom type (e.g., sadness, suicidal thoughts). The total scores on the CDI range from 0 to 16 . The final result was dichotomized to identify low and high levels of depressive symptoms. Based on previous studies, a score of 4 differentiated between children who had a high risk of depression from those with a low risk of depression (KöLTö 2014). Thus, our sample was divided into two groups (low risk of depression; high risk of depression). The scale's internal consistency showed good reliability in this study (Cronbach's alpha $=0.85$ ).

\subsection{Statistical analysis}

After the data collection, SPSS for Windows 24.0 was used for data analysis. Besides descriptive statistics (e.g., means, standard deviations, absolute and relative frequencies), the Chi-square test was used to see the significant associations in eating behavior, physical activity, screen time, substance use, and depressive symptoms. Furthermore, we used binary logistic regression to estimate odds ratio (OR) and $95 \%$ confidence interval (CI) for detecting the predictive value of each factor of the high risk of depressive symptomatology, including sociodemographic variables, eating behavior, physical activity, screen time, and substance use. A p-value of 0.05 was used to define statistical significance.

\section{Results}

The recruited participants $(\mathrm{N}=705)$ come from different regions of Hungary: $14.2 \%$ lived in the capital, $26.3 \%$ in bigger cities ( $>100,000$ inhabitants), $32.4 \%$ in smaller cities ( $\leq 100,000$ inhabitants), and the rest in rural areas (27.1\%). Most of the students lived with their parents $(67.0 \%)$, and $73.5 \%$ of participants live in family residences. The students were asked to indicate the subjective financial status of their families: $68.6 \%$ of the sample rated themselves as middle-class; $20.9 \%$ rated themselves as upper-middle-class; $7.4 \%$ rated themselves as lower-middle-class; $1.8 \%$ rated themselves as upper-class; $1.3 \%$ rated themselves as lower class. The students were also asked about the positive coronavirus test result: $95.6 \%$ of the participants reported a negative result or had never been tested, and $4.4 \%$ of the sample reported positive results on their COVID-19 test. 
Table 1 displays the absolute and relative frequencies of eating behavior, physical activity, sedentary behavior, substance use, and depressive symptoms for the participants. Daily fruit and vegetable consumption was reported by $21.7 \%$ and $22.4 \%$ of respondents respectively, with the girls being significantly more likely to eat fruits and vegetables than the boys $(p<.005)$. The proportion of the sample that consumed daily sweets was $13.2 \%$, daily soft drinks was $12.3 \%$, and daily energy drinks was $4.5 \%$. We did not find any gender differences between the consumption of sweets $(p=0.67)$, soft drinks ( $p=0.20)$, and energy drinks ( $p=0.71) .35 .5 \%$ of the sample was reported having breakfast every school day during the 'stay-at-home' era. On the weekends, the proportion that reported having breakfast on both days rises to $68.1 \%$. There were no gender differences in having breakfast on weekdays $(p=0.18)$ and weekends $(p=0.41)$ as well.

A total of $99(14.0 \%)$ students were not engaged in any physical activity during the mandatory confinement. $27.7 \%$ exercised at least one hour on one or two days a week. Over one in three of the participants did some physical activity for at least one hour on three or four days per week (36.7\%). $15.0 \%$ of them did at least an hour of training in five or six days. Only $6.5 \%$ of the sample exercised at least one hour daily. Gender differences in physical activity showed that boys had significantly more days of participating in any physical activity for at least an hour $(p<.005)$. We asked the participants about their screen time: $86.1 \%$ of them spent four or more hours on screen (e.g., tablets, PC, etc.) in the 'stay-at-home' period. Gender differences were found in screen time: the girls spent significantly more time in front of the screen than boys $(p<.005)$.

The frequencies of substance use showed that $80.1 \%$ of the sample did not smoke during the 'stay-at-home' period. However, $19.9 \%$ reported that they smoked occasionally or daily. More than half of the students (58.6\%) did not drink any alcohol, but $41.4 \%$ of the participants reported daily or occasional alcohol consumption. Most of the participants (97.0\%) did not use any illegal drugs (e.g., marijuana). Significant gender differences were found only in illegal drug use in our sample. The boys were significantly more likely to report illegal drug use in the 'stay-at-home' period than girls $(p<.005)$.

Finally, in terms of depressive symptoms, more than half of the sample reported a low risk of depression (54.6\%), and $45.4 \%$ of the adolescents belonged to the high-risk group exhibiting depressive symptoms. Significant gender differences appeared in the risk of depressive symptoms, as well: girls were more likely to belong to the high-risk group $(p<.005)$. 
Table 1

The sample characteristics of eating behavior, physical activity, sedentary behavior, substance use and depressive symptoms in the 'stay-home' period

\begin{tabular}{cccc}
\hline Variable & Total $(n=705)$ & Boys $(n=264)$ & Girls $(n=441)$ \\
\hline Daily fruit consumption during the 'stay-home' period & & \\
Yes & $21.7 \%(\mathrm{n}=153)$ & $17.8 \%(\mathrm{n}=47)$ & $24.0 \%(\mathrm{n}=106)$ \\
No & $78.3 \%(\mathrm{n}=552)$ & $82 . \%(\mathrm{n}=217)$ & $76.0 \%(\mathrm{n}=335)$
\end{tabular}

Daily vegetable consumption during the 'stay-home' period

$\begin{array}{llll}\text { Yes } & 21.4 \%(\mathrm{n}=151) & 17.0 \%(\mathrm{n}=45) & 24.0 \%(\mathrm{n}=106) \\ \text { No } & 78.6 \%(\mathrm{n}=554) & 83.0 \%(\mathrm{n}=219) & 76.0 \%(\mathrm{n}=335)\end{array}$

Daily sweets consumption during the 'stay-home'period

\begin{tabular}{|c|c|c|c|}
\hline Yes & $13.2 \%(\mathrm{n}=93)$ & $12.5 \%(n=33)$ & $13.6 \%(\mathrm{n}=60)$ \\
\hline No & $86.8 \%(n=612)$ & $87.5 \%(n=231)$ & $86.4 \%(\mathrm{n}=381)$ \\
\hline
\end{tabular}

Daily soft drink consumption during the 'stay-home' period

\begin{tabular}{|c|c|c|c|}
\hline Yes & $12.3 \%(\mathrm{n}=87)$ & $14.3 \%(\mathrm{n}=38)$ & $11.1 \%(n=49)$ \\
\hline No & $87.7 \%(n=618)$ & $85.6 \%(n=226)$ & $88.9 \%(n=392)$ \\
\hline
\end{tabular}

Daily energy drink consumption during the 'stay-home'period

$\begin{array}{llll}\text { Yes } & 4.5 \%(\mathrm{n}=32) & 4.1 \%(\mathrm{n}=11) & 4.8 \%(\mathrm{n}=21) \\ \text { No } & 95.5 \%(\mathrm{n}=705) & 95 . \%(\mathrm{n}=264) & 95.2 \%(\mathrm{n}=441)\end{array}$

Daily breakfast on weekdays during 'stay-home'period

\begin{tabular}{|c|c|c|c|}
\hline Yes & $35.5 \%(\mathrm{n}=250)$ & $41.3 \%(\mathrm{n}=109)$ & $32.0 \%(\mathrm{n}=141)$ \\
\hline No & $65.5 \%(\mathrm{n}=455)$ & $58.7 \%(\mathrm{n}=155)$ & $68.0 \%(\mathrm{n}=300)$ \\
\hline
\end{tabular}

Daily breakfast at the weekends during 'stay-home'period

\begin{tabular}{|c|c|c|c|}
\hline Yes & $68.1 \%(n=480)$ & $72.7 \%(\mathrm{n}=192)$ & $65.3 \%(\mathrm{n}=288)$ \\
\hline No & $31.9 \%(n=225)$ & $27.3 \%(\mathrm{n}=72)$ & $34.7 \%(\mathrm{n}=153)$ \\
\hline
\end{tabular}

Physical activity during the 'stay-home' period

None

$14.0 \%(\mathrm{n}=99)$

$13.6 \%(\mathrm{n}=36)$

$14.3 \%(\mathrm{n}=63)$ 


$\begin{array}{cccc}1-2 \text { days } & 27.7 \%(\mathrm{n}=195) & 22.7 \%(\mathrm{n}=60) & 30.6 \%(\mathrm{n}=135) \\ 3-4 \text { days } & 36.7 \%(\mathrm{n}=259) & 34.1 \%(\mathrm{n}=90) & 38.3 \%(\mathrm{n}=169) \\ 5-6 \text { days } & 15.0 \%(\mathrm{n}=106) & 18.9 \%(\mathrm{n}=50) & 12.7 \%(\mathrm{n}=56) \\ 7 \text { days a week } & 6.5 \%(\mathrm{n}=46) & 10.6 \%(\mathrm{n}=28) & 4.1 \%(\mathrm{n}=18)\end{array}$

Screen time during the 'stay-home' period

Less than 1 hour

$4.1 \%(\mathrm{n}=29)$

2-3 hour

$9.8 \%(\mathrm{n}=69)$

4 or more hour

$86.1 \%(\mathrm{n}=607)$

Tobacco smoking during the 'stay-home' period

$\begin{array}{cc}\text { Never } & 80.1 \%(\mathrm{n}=565) \\ \text { Occasionally/daily } & 19.9 \%(\mathrm{n}=140)\end{array}$

Alcohol consumption during the 'stay-home' period

$\begin{array}{cc}\text { Never } & 58.6 \%(\mathrm{n}=413) \\ \text { Occasionally/daily } & 41.4 \%(\mathrm{n}=292)\end{array}$

Drug abuse during the 'stay-home' period

$\begin{array}{cc}\text { Never } & 97.0 \%(\mathrm{n}=684) \\ \text { Occasionally/daily } & 3.0 \%(\mathrm{n}=21)\end{array}$

Depressive symptoms during the 'stay-home' period

Low risk of depression $\quad 54.6 \%(\mathrm{n}=383)$

High risk of depression

$45.4 \%(\mathrm{n}=318)$
$6.8 \%(\mathrm{n}=18)$

$14.4 \%(\mathrm{n}=38)$

$78.8 \%(\mathrm{n}=208)$

0.61

$79.3 \%(n=209)$

$21.7 \%(\mathrm{n}=55)$

$80.7 \%(\mathrm{n}=356)$

$19.3 \%(\mathrm{n}=121)$

0.29

$56.1 \%(\mathrm{n}=148)$

$43.9 \%(n=116)$

$<.05$

$95.1 \%(\mathrm{n}=251)$

$98.2 \%(n=433)$

$5.0 \%(\mathrm{n}=13)$

$1.9 \%(\mathrm{n}=9)$

Note. Chi-square tests.

Table 2 presents the results of the binary logistic regression analysis on the high risk of depression by sociodemographics. Girls had a significantly higher risk for depressive symptoms than boys (OR, 4.20 [95\% CI, 2.94-6.01]). Depressive symptoms were also associated with the place of residence during the 'stay-at-home' period. Participants who lived in bigger cities ( $>100,000$ inhabitants) had a 1.75 odds ratio (95\% CI, 1.03-2.96) in having a higher risk of depressive symptoms compared to those who resided in rural places. 
Table 2

Odds of high risk of depression by sociodemographics in the 'stay-home' period

\begin{tabular}{|c|c|c|c|}
\hline Variable & & OR $(95 \% C I)$ & P-value \\
\hline \multicolumn{4}{|l|}{ Gender } \\
\hline & Boy & 1 (reference) & \\
\hline & Girl & $4.20(2.94-6.01)$ & $<.001$ \\
\hline \multicolumn{4}{|l|}{ Age } \\
\hline & $14-15$ & 1 (reference) & \\
\hline & $16-17$ & $0.93(0.64-1.24)$ & 0.70 \\
\hline & $18-19$ & $0.75(0.42-1.37)$ & 0.36 \\
\hline
\end{tabular}

Living with both parents

$\begin{array}{lll}\text { Yes } & 1 \text { (reference) } & \\ \text { No } & 1.08(0.70-1.58) & 0.69\end{array}$

Living in family house

$\begin{array}{lll}\text { Yes } & 1 \text { (reference) } & \\ \text { No } & 1.10(0.68-1.79) & 0.68\end{array}$

Place of residence

$\begin{array}{rcr}\text { Rural } & 1 \text { (reference) } & \\ \leq 100000 \text { city } & 1.52(0.76-3.03) & 0.23 \\ >100000 \text { city } & 1.75(1.03-2.96) & <.005 \\ \text { Capital } & 1.53(0.96-2.46) & 0.06\end{array}$

Financial status

$\begin{array}{rcc}\text { Upper-class } & 1 \text { (reference) } & \\ \text { Upper-middle-class } & 1.56(0.38-6.42) & 0.53 \\ \text { Middle-class } & 1.85(0.46-7.35) & 0.37 \\ \text { Lower middle-class } & 1.05(0.23-4.48) & 0.94 \\ \text { Lower } & 0.74(0.08-6.17) & 0.78\end{array}$


Table 3 shows the odds involving the high risk of depression by health behaviors. Students who never participated in physical activities had a significantly higher risk for depression compared to those who exercised daily (OR, 3.10 [95\% CI, $1.45-6.65])$. One to 2 days (OR, 2.55 [95\% CI, 1.30-5.00]) and $3-4$ days (OR, 2.10 [95\% CI, 1.09-4.03]) of physical activity has also increased the odds of the high risk for depression compared to those who exercised daily. More hours of daily screen time were associated with high depression symptoms (OR, 2.27 [95\% CI, 1.14-4.61]).

\section{Table 3}

Odds of high risk of depression by eating behavior, physical activity and sedentary behavior in the 'stay-home' period

\begin{tabular}{|c|c|c|c|}
\hline Variable & & OR $(95 \% C I)$ & $P$-value \\
\hline \multicolumn{4}{|c|}{ Daily fruit consumption } \\
\hline & Yes & 1 (reference) & \\
\hline & No & $1.08(0.62-1.63)$ & 0.97 \\
\hline
\end{tabular}

Daily vegetable consumption

$\begin{array}{lcr}\text { Yes } & 1 \text { (reference) } & \\ \text { No } & 1.10(0.63-1.67) & 0.89\end{array}$

Daily sweets consumption

$\begin{array}{lcl}\text { Yes } & 1 \text { (reference) } & \\ \text { No } & 1.02(0.60-1.74) & 0.93\end{array}$

Daily soft drink consumption

$\begin{array}{lcl}\text { Yes } & 1 \text { (reference) } & \\ \text { No } & 1.30(0.75-1.24) & 0.30\end{array}$

Daily energy drink consumption 


$\begin{array}{ll}\text { Yes } & 1 \text { (reference) } \\ \text { No } & 1.36(0.62-2.98)\end{array}$

Daily breakfast

$\begin{array}{lc}\text { Yes } & 1 \text { (reference) } \\ \text { No } & 1.16(0.68-2.01)\end{array}$

Breakfast at the weekends

$\begin{array}{lc}\text { Yes } & 1 \text { (reference) } \\ \text { No } & 1.21(0.84-1.70)\end{array}$

Physical Activity

$$
\begin{aligned}
& 7 \text { days a week } \\
& \text { 5-6 days } \\
& 3-4 \text { days } \\
& 1-2 \text { days } \\
& \text { none }
\end{aligned}
$$$$
1 \text { (reference) }
$$$$
1.70(0.83-3.47)
$$

Screen time

$$
\begin{aligned}
& \text { Less than } 1 \text { hour } \\
& 2-3 \text { hours } \\
& 4 \text { or more hours }
\end{aligned}
$$$$
1 \text { (reference) }
$$$$
1.72(0.87-3.40)
$$

\begin{tabular}{|c|c|c|}
\hline Variable & OR $(95 \% C I)$ & $P$-value \\
\hline \multicolumn{3}{|l|}{ Tobacco smoking } \\
\hline Never & 1 (reference) & \\
\hline Occasionally/daily & $1.17(0.76-1.80)$ & 0.45 \\
\hline
\end{tabular}

Finally, in terms of substance use, occasional and daily alcohol consumption (OR, 1.98 [95\% CI, 1.41-2.78]) and drug use (OR, 4.97 [95\% CI, 1.40-17.53]) increased the risk of high depressive symptoms (Table 4).

\section{Table 4}

Odds of high risk of depression by substance use in the 'stay-home' period 
Alcohol consumption

$\begin{array}{rcr}\text { Never } & 1 \text { (reference) } & \\ \text { Occasionally/daily } & 1.98(1.41-2.78) & <.001\end{array}$

Drug abuse

Never 1 (reference)

Occasionally/daily $\quad 4.97(1.40-17.53)$

$<.05$

Note. Binary logistic regression analysis. OR: Odds Ratio. 95\% CI: 95\% Confidence Intervals.

\section{Discussion}

This study aimed to explore health behavior and identify the role of sociodemographics, eating behavior, physical activity, sedentary behavior, and substance use regarding depressive symptoms in Hungarian adolescents during the COVID-19 pandemic. The data were collected in the pandemic's second wave while the students were spending more than half of the year in remote study. Therefore, we aimed to detect their eating habits, physical activities, sedentary behavior, substance use and depressive symptoms during this difficult period. In particular, we wanted to explore the role health behaviors may play in the risk of developing depressive symptoms since the likelihood of developing depressive symptoms is often increased in such challenging situations (BHATIA \& BHATIA 2007).

Risk assessment in adolescence has been well established (e.g., VAN VoORHEES et al. 2008). In our results, depressive symptoms were associated with gender, place of residence, physical activity, screen time, and substance use. Our findings on gender differences were consistent with previous epidemiological studies that girls were at higher risk of depression than boys (e.g., PIEH et al. 2020; WANG et al. 2020). In terms of other sociodemographic predictors of depression, only the place of residence was significantly associated with a high risk of depressive symptoms in our study. Previous researchers showed a higher risk for depression in urban areas (VIGOD et al. 2013). Our results reflected this phenomenon; however, our findings were less consistent. As it seems, living in smaller cities or rural places is a protective factor against depression. While cities with more than 100,000 inhabitants significantly increased depression, living in the capital (more than two million inhabitants) was not reported as a significant predictor for high depressive symptoms. Empirical evidence exists regarding the effects of urbanization on depression; however, studies suggest that income has a mediating role on the association between place and depression (SAMPSON et al. 2020). Since the capital is the financial center of Hungary, most high-income families live here, which might provide protection against depressive symptoms.

Eating habits and daily breakfast consumption were not significant predictors of the high risk of depressive symptoms in our sample. On the contrary, healthy eating 
habits (e.g., eating more fruits and vegetables) were associated with depression in previous studies (LEE \& ALLEN 2021). One of the main benefits of remote schooling was the decrease in sweet beverages and energy-dense food consumption (INCHLEY et al. 2020; NÉMETH 2014). It is a welcome result since the consumption of sweets and sweetened beverages has been associated with obesity and cardiovascular risk (KAVEY 2010). However, we should acknowledge that fruit and vegetable consumption was lower in our sample than in previous studies (INCHLEY et al. 2020). These results are consistent with findings from the international literature about pandemic eating habits, where researchers found unhealthy eating patterns (e.g., Ammar et al. 2020). This means that while consuming more fruits and vegetables remains essential for young people's mental health (LEE \& ALLEN 2021), fruit and vegetable consumption did not prove to be protective factors in our study. Although girls had a healthier eating profile than boys, consuming significantly more fruits and vegetables in our research, they were more likely to have high depressive symptoms. Other studies found that meal routine (e.g., meal preparation, making more meals) was changed during the pandemic period. This can have an impact on dietary habits, which we did not measure. This change might also affect the risk of depressive symptoms in the 'stay-at-home' period (CARroll et al. 2020). Future studies should address this phenomenon.

The role of physical activity is particularly relevant for mental health and depression (VANKIM \& NeLSON 2013). We found significant associations between physical activity, sedentary behavior, and the risk of depression, similar to previous research (e.g., FENG et al. 2014; TAYLOR 2011). It seems that the risk of depression is increasing while willingness to exercise is decreasing in our study. As mentioned earlier, a global reduction of physical activity has impacted both adults and adolescents (i.e., BATES et al. 2020; CHEN et al. 2020). This is true in our study as well; only a small part of our sample participated in daily physical activity $(6.5 \%)$ during the lockdown. In comparison, daily physical activity stood at $16 \%$ in the HBSC research in 2018 (INCHLEY et al. 2020). During this period, not only was in-school physical education suspended, but the training for several sports were also canceled. Taken together, these further reduced the opportunity and motivation to participate in sports for the adolescent population. Previous studies showed the importance of social interaction in sport motivation (ORR et al. 2018), which this period rendered impossible. With a decreased physical activity, screen time significantly increased compared with previous studies (NÉMETH 2014) since the students often sat in front of their computers all day. This result was expected, and similar trends were shown in previous research. STIGLIC and VINER (2019) found higher depressive symptoms and lower levels of quality of life among adolescents who spend more time in front of a TV or a computer. Our results suggest that home-schooling might contribute to a deterioration of adolescent mental health. 
Alcohol consumption and drug use increased the odds for the high risk of depressive symptoms in our study. This result was not unexpected since the students could not meet with their friends, many leisure activities were canceled, and the 'stay-at-home' orders turned their lives upside down. As mentioned earlier, the lack of social interaction could lead to increased substance use associated with mental health issues such as depression (FAIRBAIRn \& SAYETTE 2014). Furthermore, it is plausible that adolescents had more unstructured time, which can be associated with problem behavior, including substance use (Dumas et al. 2020). Even though alcohol consumption and drug use increased the risk of depression, use was still lower compared to the HBSC study in 2018 (INCHLEY et al. 2020). Alcohol consumption in their research was $51 \%$, and in our research, $41 \%$ of the participants reported drinking during the 'stay-at-home' period. Drug use was also reported as lower compared to the HBSC results (INCHLEY et al. 2020; NÉMETH 2014). We assume that access to such substances was harder during the lockdown (CHIAPPINI et al. 2020). Interestingly, smoking was not a predictor of the high risk of depression. There is a declining trend in tobacco usage, which might explain our result. For example, according to the HBSC study in $2014,32 \%$ of adolescent boys ( $28 \%$ of the girls) smoked in their last 30 days. This result was decreased in the HBSC study in 2018 to $25 \%$ (21\% of the girls) (INCHLEY et al. 2020). In our study, $21 \%$ of the boys and $19 \%$ of the girls reported tobacco use in the 'stay-at-home' period.

\section{Conclusions}

In conclusion, our study's most important findings are the following: 1) Girls had a higher probability of depressive symptoms than boys in the 'stay-at-home' regime; 2) Physical activity appears to have had a protective role against a high risk of developing depressive symptoms; 3) Screen time, alcohol consumption and drug abuse were associated with an increased risk of depressive symptoms. Furthermore, we believe our results suggest that the increased screen time during the 'stay-athome' era, the lack of daily physical activity and the use of alcohol and illegal drugs may be associated with loneliness and they might have contributed to depressive symptoms. Further research is needed to detect these associations.

Our study has limitations that need addressing: First, due to the convenience sample, the generalizability of our results may be restricted. Second, the method of data collection, namely, social media platforms, may narrow down the participation. We must also acknowledge that our research was based on cross-sectional data. Thus, causal interpretation is not possible. For example, alcohol or other substances are often used as a way of self-medicating for depression. The measurement of sedentary behavior was also a limitation since questions about screen time were developed for non-pandemic times, hence our result might not have a high reliability. Another 
limitation of our study is the date of the data collection. According to TuCKER and GilliLAND (2007), levels of physical activity vary with seasonality. Therefore, our data collection in winter may contribute to the low level of physical activity. Finally, without a clinical diagnosis, we cannot interpret our results in terms of depression, only the risk of depressive symptoms. Future research should address longitudinal design and examine changes over time to better understand the impact of the COVID-19 pandemic on adolescent behavior and mental health. Furthermore, future studies should focus on other aspects of health behavior and depression. For example, it would be interesting to see how meal routine changes such as eating more meals may affect depressive symptoms. Other psychological variables can also be used in the future (e.g., loneliness). All in all, we believe our analysis provided useful information on adolescent health behaviors and the role these might play in the risk of depressive symptoms. We hope these results help professionals develop programs or regulations for future pandemics and lockdowns, which might help support adolescents' mental wellbeing in similar unusual circumstances.

\section{References}

Ács, P., V. Prémusz, K. Morvay-Sey, Á. Pálvolgyi, M. Trpoovici, G. Elbert, C. MElczer \& A. MaKaI (2020) 'Effects of Covid-19 on Physical Activity Behavior Among University Students: Results of a Hungarian Online Survey', Health Problems of Civilization 14(3), 174-82 (https://doi.org/10.5114/hpc.2020.98472). Ammar, A., M. Brach, K. Trabelsi, H. Chtourou, O. Boukhris, L. Masmoudi, B. Bouaziz, E. Bentlage, D. How, M. Ahmed, P. Mueller, N. Mueller, A. Aloui, O. Hammouda, L.L. Paineiras-Domingos, A. Braakman-Jansen, C. Wrede, S. Bastoni, C. Soares Pernambuco, L. Mataruna, M. Taheri, K. Irandoust, A. Khacharem, N.L. Bragazzi, K. Chamari, J.M. Glenn, N.T. Bott, F.Gargouri, L. ChaAri, H. Batatia, G.M. Ali, O. Abdelkarim, M. Jarraya, K. El Abed, N. Souissi, L.Van Gemert-Pijnen, B.L. Riemann, L. Riemann, W. Moalla, J. Gómez-Raja, M. Epstein, R. Sanderman, S. Schulz, A. Jerg, R. Al-Horani, T. Mansi, M. Jmail, F. Barbosa, F.Santos, B. Šimunič, R. Pišot, D. Cowan, A. Gaggioli, S.J. Bailey, J. Steinacker, T. Driss \& A. Hoekelman (2020) 'Effects of COVID-19 Home Confinement on Physical Activity and Eating Behaviour Preliminary Results of the ECLBCOVID19 International Online-Survey', Nutrients 12(6), 1583 (https://doi.org /10.1101/2020.05.04.20072447).

Aoun, C., L. Nassar, S. Soumi, N. El Osta, T. Papazian \& L. Rabbaa Khabbaz (2019) 'The Cognitive, Behavioral, and Emotional Aspects of Eating Habits and Association with Impulsivity, Chronotype, Anxiety, and Depression: A 
Cross-Sectional Study', Frontiers in Behavioral Neuroscience 13, 204 (https:// doi.org/10.3389/fnbeh.2019.00204).

Assari, S. (2017) 'Social Determinants of Depression: The Intersections of Race, Gender, and Socioeconomic Status', Brain Sciences 7(12), 156 (https://doi. org/10.3390/brainsci7120156).

Bates, L.C., G. Zieff, K. Stanford, J.B. Moore, Z.Y. Kerr, E.D. Hanson, B.B. GibBs, C.E. KLINE \& L. Stoner (2020) 'COVID-19 Impact on Behaviors Across the 24-Hour Day in Children and Adolescents: Physical Activity, Sedentary Behavior, and Sleep', Children 7(9), 138 (https://doi.org/10.3390/children7090138).

Behrouz, R. \& R.V. Aachi (2017) 'Letter by Behrouz and Aachi Regarding Article, "Cannabis, Tobacco, Alcohol Use, and the Risk of Early Stroke: A Population-Based Cohort Study of 45000 Swedish Men”", Stroke 48(5), e133 (https:// doi.org/10.1161/strokeaha.117.016872).

Bhatia, S.K. \& S.C. Bhatia (2007) 'Childhood and Adolescent Depression', American Family Physician 75(1), 73-80, retrieved 11 Oct 2021 from https://www. aafp.org/afp/2007/0101/p73.html.

Bobakova, D., Z. Hamrik, P. Badura, D. Sigmundova, H. Nalecz \& M. Kalman (2015) 'Test-Retest Reliability of Selected Physical Activity and Sedentary Behaviour HBSC Items in the Czech Republic, Slovakia and Poland', International Journal of Public Health 60, 59-67 (https://doi.org/10.1007/s00038-014-0628-9).

Canham, S.L., P.M. Mauro, C.N. Kaufmann \& A. Sixsmith (2016) 'Association of Alcohol Use and Loneliness Frequency Among Middle-Aged and Older Adult Drinkers', Journal of Aging and Health 28(2), 267-84 (https://doi. org/10.1177/0898264315589579).

Carroll, N., A. Sadowski, A. Laila, V. Hruska, M. Nixon, D.W.L. Ma \& J. Haines (2020) 'The Impact of COVID-19 on Health Behavior, Stress, Financial, and Food Security among Middle to High Income Canadian Families with Young Children', Nutrients 12(8), 2352 (https://doi.org/10.3390/nu12082352).

Chiappini, S., A. Guirguis, A. John, J.M. Corkery \& F. Schifano (2020) 'COVID19: The Hidden Impact on Mental Health and Drug Addiction', Frontiers in Psychiatry 11, 767 (https://doi.org/10.3389/fpsyt.2020.00767).

Chen, P., L. MaO, G.P. Nassis, P. Harmer, B.E. Ainsworth \& F. Li (2020) 'Returning Chinese School-Aged Children and Adolescents to Physical Activity in the Wake of COVID-19: Actions and Precautions', Journal of Sport and Health Science 9(4), 322-24 (https://doi.org/10.1016/j.jshs.2020.04.003).

Czeisler, M.É., R.I. Lane, E. Petrosky, J.F. Wiley, A. Christensen, R. Nuai, M.D. Weaver, R. Robbins, E.R. Facer-Childs, L.K. Barger, C.A. Czeisler, M.E. Howard \& S.M.W. RaJaratnam (2020) 'Mental Health, Substance Use, and Suicidal Ideation During the COVID-19 pandemic - United States, June 24-30, 2020', MMWR Morbidity and Mortality Weekly Report 69, 1049-57 (https://doi.org/10.15585/mmwr.mm6932a1). 
Duan, L., X. Shao, Y. Wang, Y. Huang, J. Miao, X. Yang \& G. Zhu (2020) 'An Investigation of Mental Health Status of Children and Adolescents in China During the Outbreak of COVID-19', Journal of Affective Disorders 275, 112-18 (https://doi.org/10.1016/j.jad.2020.06.029).

Dumas, T.M., W. Ellis \& D.M. LitT (2020) 'What Does Adolescent Substance Use Look Like During the COVID-19 Pandemic? Examining Changes in Frequency, Social Contexts, and Pandemic-Related Predictors', Journal of Adolescent Health 67(3), 354-61 (https://doi.org/10.1016/j.jadohealth.2020.06.018).

Dyal, S.R. \& T.W. Valente (2015) 'A Systematic Review of Loneliness and Smoking: Small Effects, Big Implications', Substance Use \& Misuse 50(13), 1697-1716 (https:/doi.org/10.3109/10826084.2015.1027933).

FAirbairn, C.E. \& M.A. SAYetTe (2014) 'A Social-Attributional Analysis of Alcohol Response', Psychological Bulletin 140(5), 1361-82 (https://doi.org/10.1037/ a0037563).

Feng, Q., Q. Zhang, Y. Du, Y. Ye \& Q. He (2014) 'Associations of Physical Activity, Screen Time with Depression, Anxiety and Sleep Quality Among Chinese College Freshmen', PLoS ONE 9(6), e100914 (https://doi.org/10.1371/journal. pone.0100914).

Harakeh, Z., M.E. de Looze, C. Schrijvers, S.A.F.M. van Dorsselaer \& W.A.M. Vollebergh (2012) 'Individual and Environmental Predictors of Health Risk Behaviours Among Dutch Adolescents: The HBSC Study', Public Health 126(7), 566-73 (https://doi.org/10.1016/j.puhe.2012.04.006).

HaWkley, L.C. \& J.T. CACIOPPO (2010) 'Loneliness Matters: A Theoretical and Empirical Review of Consequences and Mechanisms', Annals of Behavioral Medicine 40, 218-27 (https://doi.org/10.1007/s12160-010-9210-8).

Hodder, R.K., M. Freund, J. Bowman, L. Wolfenden, K. Gillham, J. Dray \& J. Wiggers (2016) 'Associations Between Adolescent Tobacco and Alcohol Use, and Tobacco and Alcohol Use Risk and Protective Factors', BMJ Open 6, e012688 (https://doi.org/10.1136/bmjopen-2016-012688).

Inchley, J., D. Currie, S. Budisavluevic, T. Torsheim, A. JÅstad, A. Cosma, C. Kelly, Á.M. Arnarsson \& O. Samdal eds., (2020) Spotlight on Adolescent Health and Well-Being: Findings from the 2017/2018 Health Behaviour in SchoolAged Children (HBSC) Survey in Europe and Canada; International Report; Volume 2. Key Data (Copenhagen: WHO) retrieved 8 Oct 2021 from https://www. euro.who.int/en/publications/abstracts/spotlight-on-adolescent-health-and-wellbeing.-findings-from-the-20172018-health-behavior-in-school-aged-childrenhbsc-survey-in-europe-and-canada.-international-report.-volume-2.-key-data. JiaO, V.Y., L.N. Wang, H. LiU, S.F. Fang, F.Y. JiaO, M. Pettoello-Mantovani \& E. Somekn (2020) 'Behavioral and Emotional Disorders in Children During the COVID-19 Epidemic', Pediatric Pharmacology 17(3), 230-33 (https://doi. org/10.15690/pf.v17i3.2127). 
KaveY, R.-E.W. (2010) 'How Sweet it Is: Sugar-Sweetened Beverage Consumption, Obesity, and Cardiovascular Risk in Childhood', Journal of the American Dietetic Association 110(10), 1456-60 (https://doi.org/10.1016/j.jada.2010.07.028).

Kovacs, V.A., G. Starc, M. Brandes, M. Kaj, R. Blagus, B. Leskošek, T. Suesse, E. Dinya, B.C. Guinhouya, V. Zito, P.M. Rocha, B.P. Gonzalez, A. KontSevaya, M. Brzezinski, R. Bidiugan, A. Király, T. Csányi \& A.D. OKely (2021) 'Physical Activity, Screen Time and the COVID-19 School Closures in Europe - An Observational Study in 10 Countries', European Journal of Sport Science 1-10 (https://doi.org/10.1080/17461391.2021.1897166).

KöLTő, A. (2014) 'Szubjektív jóllét és egészségi állapot' [Subjective well-being and mental health], in A. Németh \& A. KöLTö, eds., Egészség és egészségmagatartás iskoláskorban 2014: Az Iskoláskorú gyermekek egészségmagatartása elnevezésü, az Egészségügyi Világszervezettel együttmüködésben megvalósuló nemzetközi kutatás 2014. évi felméréséröl készült nemzeti jelentés [Health Behaviour in School-aged Children (HBSC): A WHO-collaborative Cross-National Study National Report] 132-49, retrieved 10 Oct 2021 from https://mek. oszk.hu/16100/16119/16119.pdf.

Lee, J. \& J. Allen (2021) 'Gender Differences in Healthy and Unhealthy Food Consumption and its Relationship with Depression in Young Adulthood', Community Mental Health Journal 57, 898 - 909 (https://doi.org/10.1007/ s10597-020-00672-x).

López-Bueno, R., G.F. López-Sánchez, J.A. Casajús, J. Calatayud, A. GilSalmerón, I. Grabovac, M.A. Tully \& L. Smith (2020) 'Health-Related Behaviors Among School-Aged Children and Adolescents During the Spanish COVID-19 Confinement', Frontiers in Pediatrics 8 (https://doi.org/10.3389/ fped.2020.00573).

Monostori, J. (2021) The School Year 2020-2021 In Hungary During the Pandemic - Country Report (Luxembourg: Publications Office of the European Union). Morvai-Sey, K., Á. PÁlvölgyi, V. Prémusz, P. Ács, M. Stocker, A. Makai, C. Melczer, T. Laczkó, A. Szentei \& D. PaÁr (2020) 'A COVID-19 kijárási korlátozás első hullámának hatása a magyar felnőtt lakosság szubjektív pszichés mutatóira, jóllétére, fizikai aktivitására és sportolási szokásaira' [The impact of the first wave of the COVID-19 restriction on the mental well-being, physical activity among Hungarian adults] in M. Antal \& R. Pilling, eds., A magyar lakosság életmódja járványhelyzet idején: táplálkozás, testmozgás és lélek [The lifestyle of the Hungarian population during the pandemic: Nutrition, Exercise and Mind] (Budapest: Táplálkozás, Életmód és Testmozgás Platform Egyesület) 80-87, retrieved 10 Oct 2021 from https://tetplatform.hu/wp-content/ uploads/2020/12/Koronavirus_es_eletmod_TET_Platform_feher_konyv.pdf.

NÉmeTH, A. (2014) 'Táplálkozási szokások és fogápolás' [Eating habits and dental care] in A- NÉMETH \& A. KöLtö, eds., Egészség és egészségmagatartás is- 
koláskorban 2014: Az Iskoláskorú gyermekek egészségmagatartása elnevezésü, az Egészségügyi Világszervezettel együttmüködésben megvalósuló nemzetközi kutatás 2014. évi felméréséröl készült nemzeti jelentés [Health Behaviour in School-aged Children (HBSC): A WHO-collaborative Cross-National Study National Report] 18-30, retrieved 10 Oct 2021 from https://mek.oszk. hu/16100/16119/16119.pdf.

OrR, K., K.A. Tamminen, S.N. Sweet, J.R. Tomasone \& K.P. Arbour-Nicitopoulos (2018) " "I've Had Bad Experiences with Team Sport": Sport Participation, Peer Need-Thwarting, and Need-Supporting Behaviors Among Youth Identifying with Physical Disability', Adapted Physical Activity Quarterly 35(1), 36-56 (https://doi.org/10.1123/apaq.2017-0028).

Pappa, S., V. Ntella, T. Giannakas, V.G. Giannakoulis, E. Papoutsi \& P. Katsaounou (2020) 'Prevalence of Depression, Anxiety, and Insomnia among Healthcare Workers During the COVID-19 Pandemic: A Systematic Review and Meta-Analysis', Brain, Behavior, and Immunity 88, 901-907 (https://doi. org/10.1016/j.bbi.2020.05.026).

Patanavanich, R., \& S.A. Glantz (2020) 'Smoking is Associated with COVID-19 Progression: A Meta-Analysis', Nicotine \& Tobacco Research 22(9), 1653-56 (https://doi.org/10.1101/2020.04.13.20063669).

Pieh, C., S. Budimir \& T. Probst (2020) 'The Effect of Age, Gender, Income, Work, and Physical Activity on Mental Health During Coronavirus Disease (COVID-19) Lockdown in Austria', Journal of Psychosomatic Research 136, 110186 (https://doi.org/10.1016/j.jpsychores.2020.110186).

Ran, L., W. Wang, M. Ai, Y. Kong, J. Chen \& L. Kuang, L. (2020) 'Psychological Resilience, Depression, Anxiety, and Somatization Symptoms in Response to COVID-19: A Study of the General Population in China at the Peak of its Epidemic', Social Science \& Medicine 262, 113261 (https://doi.org/10.1016/j. socscimed.2020.113261).

Sampson, L., C.K. Ettman \& S. Galea (2020) 'Urbanization, Urbanicity, and Depression: A Review of the Recent Global Literature', Current Opinion in Psychiatry 33(3), 233-44 (https://doi.org/10.1097/yco.0000000000000588).

Sidor, A. \& P. Rzymski (2020) 'Dietary Choices and Habits During COVID19 Lockdown: Experience from Poland’, Nutrients 12(6), 1657 (https://doi. org/10.3390/nu12061657).

Stiglic, N. \& R.M. Viner (2019) 'Effects of Screentime on the Health and Well-Being of Children and Adolescents: A Systematic Review of Reviews', BMJ Open 9(1), e023191 (https://doi.org/10.1136/bmjopen-2018-023191).

TAYLOR, O.D. (2011) 'Adolescent Depression as a Contributing Factor to the Development of Substance Use Disorders', Journal of Human Behavior in the Social Environment 21(6), 696-710 (https://doi.org/10.1080/10911359.2011.583519). 
Tucker, P. \& J. Gilliland (2007) 'The Effect of Season and Weather on Physical Activity: A Systematic Review', Public Health 121(12), 909-22 (https://doi. org/10.1016/j.puhe.2007.04.009).

VanKim, N.A. \& T.F. Nelson (2013) 'Vigorous Physical Activity, Mental Health, Perceived Stress, and Socializing Among College Students', American Journal of Health Promotion 28(1), 7-15 (https://doi.org/10.4278/ajhp.111101-quan-395).

Van Voorhees, B.W., D. Paunesku, J. Gollan, S. Kuwabara, M. Reinecke \& A. BAsu (2008) 'Predicting Future Risk of Depressive Episode in Adolescents: The Chicago Adolescent Depression Risk Assessment (CADRA)', The Annals of Family Medicine 6(6), 503-11 (https://doi.org/10.1370/afm.887).

Vigod, S.N., L.A. Tarasoff, B. Bryja, C.-L. Dennis, M.H. Yudin \& L.E. Ross (2013) 'Relation Between Place of Residence and Postpartum Depression', Canadian Medical Association Journal 185(3), 1129-35 (https:/doi.org/10.1503/ cmaj.122028).

Wang, X., S. Hegde, C. Son, B. Keller, A. Smith \& F. Sasangohar (2020) 'Investigating Mental Health of US College Students During the COVID-19 Pandemic: Cross-Sectional Survey Study', Journal of Medical Internet Research 22(9), e22817 (https://doi.org/10.2196/22817).

WHO (2013) Global Action Plan for the Prevention and Control of Noncommunicable Diseases 2013-2020 (Geneva: World Health Organization) retrieved 11 Oct 2021 from https://apps.who.int/iris/bitstream/handle/10665/94384/9789241506236_ eng.pdf?sequence $=1 \&$ is Allowed $=\mathrm{y}$.

Zhou, J., X. Yuan, H. Qi, R. Liu, Y. Li, H. Huang, X. Chen \& G. Wang (2020) 'Prevalence of Depression and its Correlative Factors among Female Adolescents in China During the Coronavirus Disease 2019 Outbreak', Globalization and Health 16, 69 (https://doi.org/10.1186/s12992-020-00601-3). 